\title{
Assessing Brand Origin Recognition Accuracy and Its Antecedents in a Developing Country
}

\begin{abstract}
The present study aims to examine: (1) what are the brand origin recognition accuracy (BORA) scores for both foreign and local brands among Indonesian consumers? (2) are socio-economic characteristics, international experience and demographic factors related to consumers' BORA? The present research follows BORA procedures in the selection of 88 brands. The BORA scores for both foreign and local brands were relatively low. BORA was generally related to socio-economic characteristics, but only partially related with international experience, gender, and age. Most consumers were unable to differentiate brand origins because of the use of foreign languages for the brand names.
\end{abstract}

Keywords: Brand Origin Recognition Accuracy (BORA), Indonesia. 


\section{Introduction}

Globalization has resulted in ever-expanding purchase options, including an increasing proportion of foreign products and brands (Ioannou \& Rusu, 2012; Schuiling \& Kapferer, 2004). Research has indicated that brand origin recognition is one of the important factors affecting consumer perceptions of brand product quality, which in turn influences consumers’ purchase intentions.

The brand origin construct is different from country-of-origin, country-of assembly, country-of-manufacture, country-of-component, and other such constructs that focus more on the products. Brand origin will not change, even though the actual manufacturing location may. Therefore, brand origin is not always the same as the country stated in the made-in labels on most products (Thakor \& Kohli, 1996). In their study of brand origin recognition accuracy (BORA), Samiee, et al. (2005) found that BORA is dependent largely on association of brand names with languages representing the countries of origin for those brands. Studies have shown that consumers in developed economies prefer local brands and resist foreign brands (Albaum \& Peterson, 1984; Netemeyer, Durvasula \& Lichstenstein, 1991) while consumers in developing economies prefer foreign brands (Batra et al., 2000; Steenkamp, Batra \& Alden, 2002), especially for luxury brands (Zhou \& Belk, 2004). Thus, the aim of the present research is to replicate, with some modification, the study of Samiee, et al. (2005), who investigated the BORA of American consumers. Indonesia was chosen as the research context for the present study. Its huge population ( \pm 240 million people in 2011 ; Population Reference Bureau, 2011) and high economic growth (6.5\% in 2011; CIA World Factbook, 2013) has attracted foreign investors and their brands to enter the country. Therefore, it is appropriate for a study of brand origin recognition accuracy and its antecedents in Indonesia. 
Specifically, the current study will examine two main questions. First, how accurate are Indonesian consumers in recognizing brand origins of both foreign and local brands? Second, what are the relationships between socio-economic characteristics (education and income), international experiences (international travel experience and foreign language skills), and demographic factors (age and gender) and the BORA of Indonesian consumers?

\section{Literature Review and Hypotheses Development}

Brand is one of the most important intangible assets of an organization. Brand offers a number of benefits for both producers (e.g., identification, legal protection, quality level signal) and consumers (e.g., identification, practicality, guarantee, hedonistic, and ethics) (Kapferer, 2012; Keller, 2008). Not only a brand can affect consumer perception of product quality (Han \& Terpstra, 1988), but it can also create a specific association related to the image of its origin (Leclerc, Schmitt \& Dube, 1994; Thakor \& Lavack, 2003).

In response to conceptual inadequacies of the country of origin concept, Samiee, et al. (2005) proposed the concept of 'brand origin recognition accuracy' (BORA). Samiee, et al. (2005, p. 382) defined BORA as "the country a brand is associated with or the headquarters of where the brand's owner is perceived to be located, regardless of where it is manufactured”. In reality, target consumers may perceive brand origin differently due to “ignorance, lack of salience of origin information for a particular brand, or deliberate obfuscation by company concerned about consumer reactions to unfavourable origin” (Thakor \& Kohli 1996, p. 27). Cross-border acquisitions of brands and "foreignness advantage of local brands” (e.g., using international celebrities in ads) have also contributed to the difficulty faced by consumers in identifying brand origins (Zhou, Yang \& Hui, 2010). However, Balabanis and Diamantopoulos (2008) suggested that brand origin should be the 
origin of a brand based on actual geographical location, not the place target consumers perceive.

Studies have shown that product evaluation and consumers' willingness to buy are related to brand origin (Balabanis \& Diamantopoulos, 2008; Laroche et al., 2005; Samiee et al., 2005). Brand origin is also an important determinant of brand equity, purchase decisionmaking, and brand selection (Yasin, Noor \& Mohamad, 2007). In conclusion, brand origin affects consumers' perceptions, attitudes, and intentions to buy (Magnusson et al., 2011; Papadopoulos \& Heslop, 2002; Samiee, et al., 2005).

Thakor and Kohli (1996) and Samiee (2011) argued that for numerous well-known brands, especially global brands, the brand countries of origin are easily identified, such as Samsung, Hyundai, Toyota, Mercedes Benz and Volkswagen. Nonetheless, branding strategy practices, such as foreign branding, have contributed to the complexity of identifying brand countries of origin. Foreign branding is defined as a strategy to name a product based on a foreign spelling or pronunciation with the purpose of creating an image according to that particular foreign country (Leclerc et al., 1994). As a result, the country of origin of a brand may not be identified by simply looking at its name. Several examples include Haagen-Dazs (the United States), Lego (Denmark), Nokia (Finland), Lenovo (the PRC), and so forth.

In the context of developing countries, foreign brands tend to have higher status than local brands (Agbonifoh \& Elimimian, 1999; Alden et al., 1999). Batra et al. (2000) suggested several reasons for this. First, imports are usually more expensive and limited than local brands, making them more desirable from a reference group perspective (Bearden \& Etzel, 1982). Second, consumers in developing countries are generally less affluent than their counterparts in developed countries. This result in a sense of inferiority, which in turn makes consumers in developing countries want to participate in the global consumers' community through acquiring foreign brands (Venkatesh \& Swamy, 1994). Consequently, many 
companies operating in developing countries create foreign brands to escalate the image of their brands (Ger \& Belk, 1996). Tjiptono (2010) found that only about 59\% of 135 respondents in Indonesia could accurately identify a pharmaceutical company named K-24 as originating from Indonesia. Samiee, et al. (2005) suggested that the accuracy of identifying the brand origin is related with socio-economic characteristics, education, international experiences (overseas travelling and ability to speak foreign languages), demographic characteristics (age and gender) and consumer ethnocentrism.

Research on brand origin has used categorization theory perspective to understand how consumers classify a brand as belonging to a country of origin (Balabanis \& Diamantopoulos, 2008, 2011; Martin \& Cervino, 2011; Samiee, et al., 2005). Consumers use their knowledge about a brand and its relevant attributes as the bases for associating the brand with a particular country. Perceived linguistic cues are often used to classify brands in terms of their national origin (Usunier, 2011). Despite consumers' knowledge on the brand countries of origin is still relatively limited (Balabanis \& Diamantopoulos, 2008), their accuracy in identifying the origins is higher for local brands than for foreign brands (Samiee, et al., 2005). Local brands are assumed to have better exposure, familiarity, and experience than foreign brands (Martin \& Cervino, 2011). Therefore, for Indonesian consumers, we propose the following hypotheses:

$\mathbf{H}_{\mathbf{1}}$ : Brand origin recognition accuracy (BORA) for local brands is higher than the accuracy of identifying foreign brands.

Better educated and higher income consumers have been suggested to be able to interpret brand origin information more accurately than those with lower education and income levels (Martin \& Cervinho, 2011). Previous studies found empirical support for this 
assumption (Martin \& Cervinho, 2011; Paswan \& Sharma, 2004; Samiee et al., 2005). As a result, the following hypothesis can be formulated ${ }^{1}$.

$\mathbf{H}_{2}$ : Consumers with high socioeconomic status have high BORA for foreign and local brands.

Consumers who have traveled abroad and are able to speak foreign languages are expected to have better exposure, familiarity, and experience with foreign brands than those who never visited other countries and can not speak any foreign languages. Consequently, they are assumed to have a better ability to recognize foreign brands. Samiee, et al. (2005) found that international experiences (international travel and foreign language expertise) are significantly related to the accuracy of identifying foreign brand origins but are not significantly associated with the accuracy of identifying the local brand origins. Another study showed that consumers with overseas travel experiences have higher knowledge of brand countries of origin (Paswan \& Sharma, 2004). Thus, we propose the following hypotheses.

$\mathbf{H}_{3 \mathbf{a}}$ : Consumers with high international experiences have high BORA for foreign brands.

$\mathbf{H}_{3 \mathbf{b}}$ : The level of international experience is not significantly related to BORA for local brands.

Schooler (1971) found that older consumers evaluate foreign products more favorably than local products and female consumers prefer foreign products more than male consumers. Hong and Toner (1989) suggested that when consumers evaluate familiar products, they use specific product attributes instead of brand origins; however, when they evaluate unfamiliar products, they rely on brand origin or the reputation of a particular country as the main evaluation criterion. This applied to both male and female consumers. However, Samiee, et al. (2005) revealed that age was not significantly related with BORA for either foreign or

Please refer to Martin \& Cervinho (2011) for further discussion on this issue. 
local brands. Male consumers had better BORA scores for foreign brands than female consumers did. In contrast, Balabanis and Diamantopoulus (2008) showed that women and older consumers have higher BORA for foreign brands. In the present research, demographic factors were expected to be related to BORA. Thus, we propose the following hypotheses.

$\mathbf{H}_{4 \mathbf{a}}$ : Age is related with BORA for foreign and local brands.

$\mathbf{H}_{\mathbf{4 b}}$ : Men have higher BORA for foreign and local brands than women.

\section{Methodology}

\section{Data Collection and Questionnaire Design}

Accuracy is based on respondents' correct recognition of countries of origin from a list of foreign and local brands presented to them. Brand origin is defined as the location of the head office of the company that owns the brand name (Liefeld, 2004). In this context, foreign brands were brands originating from outside Indonesia yet widely available in the Indonesian market. Local brands were brands originating in Indonesia. This study includes an examination of several antecedents of BORA. Data were collected online and offline through questionnaires completed by convenience samples of Indonesian citizens with various demographic profiles. Online questionnaires were distributed through Facebook; Kaskus.com. For the offline method, questionnaires were distributed to the surrounding area and student populations of a major private university in Yogyakarta (Indonesia).

Although procedures developed by Samiee, et al. (2005) were employed in the present study, an expert panel adapted the brands used in the questionnaires to the context of Indonesia. The specific procedures consist of three main stages: the selection of the expert panel members, the development of the list of foreign and local Indonesian brands, and the selection of brands used in the present study. Brands nominated by all three panel members were selected for the survey. This procedure resulted in 44 foreign brands and 14 local brands. The other 30 local brands were selected from those nominated by two of the three 
expert panel members. As a result, 44 foreign brands and 44 local brands, a total of 88 , were used in the present study (see Table 1).

The questionnaire consisted of two main parts. The focus of the first part was demographic factors (gender and age), socioeconomic status (education and income), and international experience (international travel and foreign language expertise). The second part contained the list of 88 brands in alphabetical order. Respondents were asked to identify the country origin for each brand by choosing one of the available options (France, the PRC, Indonesia, the United States, Italy, Germany, the United Kingdom, Switzerland, Japan, "Don’t Know”, and “Not Listed”). Information concerning the product category of each brand was provided in the questionnaire.

\section{Insert Table 1 about Here}

\section{Sample}

We received 138 responses from the offline data collection and 163 responses from the online method for a total of 301 respondents. Cross-tabulations of the offline and online samples revealed statistically significant different proportions of gender $\left(X^{2}=23.336\right.$; $\rho=$ $0.000)$, age $\left(X^{2}=37.989 ; \rho=0.000\right)$, education $\left(X^{2}=57.754 ; \rho=0.000\right)$, income $\left(X^{2}=\right.$ 18.061; $\rho=0.000)$, foreign countries visited $\left(X^{2}=54.224 ; \rho=0.000\right)$, and foreign languages spoken $\left(X^{2}=20.358 ; \rho=0.000\right)$. It suggests that both samples need to be analyzed separately. $^{2}$

\section{Results}

\section{BORA for Foreign and Local Brands}

Table 2 is a summary of BORA scores for both foreign and local brands. The BORA levels for foreign brands were quite low, with only $33.48 \%$ correctly identified in the online

\footnotetext{
2 We thank an anonymous reviewer for this suggestion.
} 
sample and $23.25 \%$ in the offline sample. About $42.51 \%$ of the online respondents and $43.07 \%$ of the offline sample misidentified the countries of origin. Meanwhile, those who said they did not know the countries of origin of the examined foreign brands were $24.01 \%$ and $33.68 \%$ of the online and offline samples, respectively. For local brands, $56.65 \%$ of the online respondents correctly identified Indonesia as the country of origin; $43.35 \%$ of them either misidentified or did not know the country of origin. Only about half (50.56\%) of the offline respondents were able to recognize the Indonesian brands. Results from paired sample t-tests indicated that the $\mathrm{BORA}_{\text {local }}$ scores were significantly higher than the $\mathrm{BORA}_{\text {foreign }}$ scores for both the online and offline samples (56.65\% vs. 33.48\% $(\rho=0.000)$ and $50.56 \%$ vs. $23.25 \%(\rho=0.000)$, respectively). Thus, $\mathrm{H}_{1}$ was supported.

Table 2 indicates that online respondents had statistically significant higher BORA scores for both local and foreign brands than the offline sample (33.48\% vs. $23.25 \%$ for foreign brands, $\rho=0.000$; and $56.65 \%$ vs. $50.56 \%$ for local brands, $\rho=0.009$ ). It may be because the online sample consists of people with better education and more international experiences.

Tables 3a-b summarize BORA scores based on brand countries of origin. Despite some differences, the results are generally consistent across the two samples (online and offline). The two highest BORA scores were for the two Chinese brands (65.34\% for online and $57.97 \%$ for offline samples) and 44 Indonesian brands (56.65\% for online and $50.56 \%$ for offline respondents). Brands from the USA and Germany had the lowest BORA scores, where only $29.54 \%$ of the online and $19.57 \%$ of the offline respondents were able to recognize 7 American brands and fewer respondents (26.50\% of the online and $15.36 \%$ of the offline samples) could identify 5 German brands.

Of the nine countries provided as the options in the questionnaire, Indonesia was identified most frequently, with an average of $15.55 \%$ of the offline and $13.03 \%$ of the online 
respondents choosing it as the brand origin. This response was followed by the PRC $(10.43 \%$ for the offline and $10.12 \%$ of the online samples), the United States (9.14\% and 10.91\%), and Japan (7.93\% and $8.90 \%)$. Selection of the remaining countries ranged from $7.89 \%$ of the online respondents for Germany to $1.98 \%$ of the offline sample for the United Kingdom. These data show that Indonesian consumers are highly exposed to products and brands from China, Japan, and the United States in addition to local brands. In fact, these three countries were among the top five trading partners of Indonesia in 2012 (The Jakarta Post, 2013). Thus, respondents are more familiar with these countries and may associate them (either correctly or incorrectly) as the countries of origin for many foreign brands.

The highest BORA scores, with $65.34 \%$ of the online and $57.97 \%$ of the offline respondents correctly identified brand origins, were for the two Chinese brands, Jialing and TCL. Chinese products and brand names are very prevalent in Indonesia. Because respondents seemed to be very familiar with Chinese brands, $5.30 \%$ of the online and $6.49 \%$ of the offline samples misperceived Indonesian brands as Chinese brands. German brands had the lowest BORA scores (26.50\% for the online and $15.36 \%$ for the offline samples); $22.58 \%$ of the online and $17.97 \%$ of the offline respondents perceived them as American brands. In addition, respondents associated some of the brands with the United Kingdom, even though no UK brands were included in the questionnaires.

Respondents perceived some foreign brands as local brands. For example, American and Swiss brands were the two most misidentified as local brands. Some other brands whose countries of origin not listed in the questionnaire (e.g., Bata footwear and Rotiboy bakery) were also perceived as local brands by many respondents. Bata has been in Indonesia for decades, and many of its products have been manufactured in Indonesia. Thus, many consumers tend to see them as local brands. Meanwhile, by using the word Roti ("bread" in Bahasa Indonesia) in its brands, Rotiboy may be misperceived by some consumers as an 
Indonesian brand. Rotiboy actually originated in Malaysia, whose language (Malay) is similar to Bahasa Indonesia.

Tables 3a-b also indicate that $15.66 \%$ of the online and $21.41 \%$ of the offline respondents did not know the country origin of several Indonesian brands. This cannot be considered a small number because the brands originated from the respondents' own country. These data may be due to the use of foreign names supported with foreign marketing slogans and models in the ads for some of these local products. For example, Lea jeans, Buccheri shoes, Excelso coffee, and Texas Chicken fast food had lower BORA scores than other local brands. The owners of these brands may want to create foreign brand images for their products because some Indonesian consumer segments tend to prefer foreign brands, perceiving them as having higher quality and more prestige.

Respondents associated some of the brands with countries of origin not listed in the questionnaire. Indeed, we purposely included some brands from South Korea, the Netherlands, Czech Republic, Canada, Finland, Malaysia, and India in the survey but did not include these countries as choices in the questionnaire. However, we did include the option of "not listed".

The low accuracy in identifying brand origins may be due to several factors, such as lack of available information when consumers are making purchase decisions. Consumers may also be misled by the languages used for brand names when they are looking for information about products. They may also be misled by the images created by the companies. Nonetheless, the findings of the present study support the findings of Samiee, et al. (2005) who found that Americans’ BORA for foreign brands (22.3\%) was low but was much higher (49\%) for local brands. Similarly, Balabanis and Diamantopoulos (2008) reported that the accuracy of UK consumers in recognizing the countries of origin for several microwave oven brands was only $27 \%$. 


\section{Antecedents of BORA}

Table 4 is a summary of the associations between several antecedents and BORA. The ANOVA tests produced mixed results. Socio-economic factors (education and income) were found to be significantly related with BORA for foreign brands in both samples. The highest average BORA scores for foreign brands were for respondents with postgraduate degrees. Thus, the higher the education level, the higher the BORA scores or the greater the ability to recognize foreign brand origins accurately. This finding is consistent with the findings of Martin and Cervino (2011) in their study of brand country of origin recognition among internet users. However, education level was only related with the ability to recognize local brands in the online sample. Similar findings were revealed for those with higher income levels. These respondents had higher BORA scores for foreign brands in both samples and for local brands among the offline sample. It suggests that higher purchasing power and education (knowledge) levels increase consumers' familiarity with various brands. Therefore, $\mathrm{H}_{2}$ was generally supported.

In terms of international experience, BORA scores were only significantly different for 3 out of 8 situations. The number of foreign countries visited was only positively related to BORA scores for local brands among the online sample. The average BORA scores for local brands were significantly different between those who had never traveled overseas (52.00\%) and those who had done so (56.02\%-64.33\%). This suggests that consumers who

travel overseas have a better understanding of which brands are local (found only in Indonesia) and which are truly foreign brands.

BORA scores were significantly different for foreign language skills only among the offline respondents. The average BORA scores of foreign and local brands for those who 
could not speak other languages were $14.89 \%$ and $41.51 \%$, respectively. These scores were significantly lower than of respondents who spoke at least one foreign language. Individuals who speak a foreign language are more familiar with foreign brands than those who cannot speak any foreign languages. They are not easily misled by foreign branding strategies, which employ foreign words, terms, pronunciation, and/or spelling for particular products. However, this result was not found in the online sample. Therefore, $\mathrm{H}_{3 a}$ was partially supported, whereas $\mathrm{H}_{3 \mathrm{~b}}$ was not supported.

In terms of age, 45-54 years old respondents in the offline sample consistently had the best BORA scores for foreign and local brands. This finding supports Balabanis and Diamantopous' study (2008), which showed that older consumers have higher BORA scores for foreign brands. Nevertheless, no significant differences were found for BORA scores across age groups in the online sample. Therefore, $\mathrm{H}_{4 \mathrm{a}}$ was partially supported.

Men had significantly higher average BORA scores for foreign brands than women (27.73\% vs. 21.73\%) among the offline sample. However, BORA scores for local brands were not significantly different between genders for both samples. Hence, $\mathrm{H}_{4 b}$ was partially supported..

\section{Insert Table 4 about Here}

\section{Theoretical and Managerial Implications}

The present study revealed that BORA scores for foreign and local brands are relatively low in Indonesia. On the one hand, the low BORA scores may be due to the high number of Indonesian brands which adopted foreign branding strategy (Leclerc, et al., 1994), such as using English looking names (e.g., Eagle), Chinese names (e.g., Dji Sam Soe), Japanese names (e.g., Shinzui), and Italian sounding name (e.g., Buccheri). Foreign names were used with present or future plans to internationalize the brands (Zhuang, et al., 2008) or 
simply to create a better image of foreign-origin brands. While consumers in general use brand name as a surrogate indicator of brand origin (Liefeld, 2004), the use of foreignsounding brand names has caused brand origin confusion (Zhuang et al., 2008). On the other hand, low BORA scores among Indonesian consumers may indicate that brand origin is not important for them when making purchase decision (Liefeld, 2004).

The current study found that Indonesian consumers are more familiar with and better able to identify the origin of their local brands than foreign brands. Better exposure, familiarity, and experience with local Indonesian brands may account for this. Interestingly, Chinese brands had a high BORA score among Indonesian consumers. Products and brands from China can be found easily in Indonesia. The low prices have been the main attractive factor of their popularity in Indonesia.

BORA scores are generally related with socio-economic characteristics, but only partially related with international experience, gender, and age. The online sample had significantly different characteristics from the offline sample. It had also shown a better ability to recognize both foreign and local brands than the offline sample. It may suggest that consumers with internet access have better knowledge of origins of brands. Managers may consider this strategy when promoting brands through online media.

In conclusion, many Indonesian consumers are unaware of brand origins, whether foreign or local. Companies should use this as a reference in deciding whether they are portraying the brand image they intend in their branding strategies. When companies find that consumer perceptions of brand origin are different from the intended strategies, companies should alter and adapt accordingly. Zhuang et al. (2008), for example, found that when a local brand is misperceived as a foreign brand, consumer preferences for the brand will increase. Therefore, managers should examine the association between the language used on 
their brands and the country images potrayed from the brand names, packaging, advertising copy, and marketing communications in general.

\section{Limitations and Future Research Directions}

Several limitations of the present study should be noted. First, the use of convenience sampling may limit the generalizability of the research findings. Future research should use a more representative sample. Second, there may be a potential bias in the brand selection process. The ability of respondents to recognize brand origins seems to be sensitive to the research design, including the choice of brands, product categories, and countries of origin (Usunier, 2011). Future researchers may wish to increase the number of expert panel members used in selecting brands for BORA studies to reduce bias in the selection process. However, the optimum number of brands used needs to be considered carefully to avoid respondent fatigue. Third, several control variables (e.g., market share and time in the market) may be added to reduce the potential bias in brand selection. However, market share and 'time in the market' data are not readily available for the current study. Future studies might include these variables in the research design. Additional research should also be done concerning BORA. Future research should include an investigation of products specifically targeted for female and male consumers to validate BORA levels further. The impact of BORA on brand preference and purchase intention in Indonesia or other developing countries deserves further investigation. The comparison of BORA scores between online and offline samples may also be another topic of future study. Finally, this study was unable to include the non-response bias analysis which may explore the potential answers of those who did not participate in the study. 


\section{References}

Agbonifoh, B.A. \& Elimimian, J.U. (1999). Attitudes of developing countries towards 'country-of-origin' products in an era of multiple brands. Journal of International Consumer Marketing, 11 (4), 97-116.

Albaum, G. \& Peterson, R.A. (1984). Empirical research in international marketing 19761982. Journal of International Business Studies, 15 (Spring/Summer), 161-173.

Alden, D.L., Steenkamp, J.-B., \& Batra, R. (1999). Brand positioning through advertising in Asia, North America, and Europe. Journal of Marketing, 63, 75-87.

Balabanis, G. \& Diamantopoulus, A. (2008). Brand origin identification by consumers: A classification perspective. Journal of International Marketing, 16 (1), 39-71.

Balabanis, G. \& Diamantopoulos, A. (2011). Gains and losses from the misperception of brand origin. Journal of International Marketing, 19 (2), 95-116.

Batra, R., et al. (2000). Effects of brand local and foreign origin on consumer attitudes in developing countries. Journal of Consumer Pyschology, 9 (2), 83-95.

Bearden, W.O. \& Etzel, M.J. (1982). Reference group influece on product and brand purchase decision. Journal of Consumer Research, 9, 183-194.

CIA World Factbook (2013). Indonesia. Retrieved from: https://www.cia.gov/library/publications/the-world-factbook/geos/id.html

Ger, G. \& Belk, R.W. (1996). I'd like to buy the world a Coke: Consumption scales of the less affluent world. Journal of Consumer Policy, 19, 271-304.

Han, C.M. \& Terpstra, V. (1988). Country of origin effects for uni-national and bi-national products. Journal of International Business Studies, 19 (2), 235-352.

Hong, S. \& Toner, J.F. (1989). Are there gender differences in the use of country-of-origin information in the evaluation of products? Advances in Consumer Research, 16, 468472.

Ioannou, M., \& Rusu, O. (2012). Consumer-based brand equity: A cross-cultural perspective. Journal of Promotion Management, 18 (3), 344-360.

Jin, Z., Chansarkar, B. \& Kondap, N.M. (2006). Brand origin in an emerging market. Asia Pacific Journal of Marketing, 18 (4), 283-302.

Kapferer, J.N. (2012). The new strategic brand management. (5 ${ }^{\text {th }}$ ed.). London: Kogan Page.

Keller, K.L. (2008). Strategic brand management. ( $3^{\text {rd }}$ ed.). Upper Saddle River, NJ.: Pearson Education International.

Laroche, M., et al. (2005). The influence of country image structure on consumer evaluations of foreign products. International Marketing Review, 22 (1), 96-115. 
Leclerc, F., Schmitt, B.H. \& Dube, L. (1994). Foreign branding and its effects on product perceptions and attitudes. Journal of Marketing Research, 31 (2), 263-271.

Liefeld, J.P. (2004). Consumer knowledge and use of country-of-origin information at the point of purchase. Journal of Consumer Behaviour, 4 (2), 85-96.

Magnusson, P., Westjohn, S.A. \& Zdravkovic, S. (2011). "What? I thought Samsung was Japanese”: Accurate or not, perceived country of origin matters. International Marketing Review, 28 (5), 454-472.

Martin, O.M. \& Cervino, J. (2011). Towards an integrative framework of brand country of origin recognition determinants: A cross-classified hierarchical model. International Marketing Review, 28 (6), 530-558.

Netemeyer, R., Durvasula, S. \& Lichtenstein, D.R. (1991). A cross-national assessment of the reliability and validity of the CETSCALE. Journal of Marketing Research, 18 (3), 320-327.

Papadopoulos, N. \& Heslop, L. (2002). Country equity and country branding: Problems and prospects. Journal of Brand Management, 9 (4/5), 294-314.

Paswan A.K. \& Sharma, D. (2004). Brand-country of origin (COO) knowledge and COO image. The Journal of Product and Brand Management, 13 (3), 144-155.

Population Reference Bureau (2011). The world at 7 billion: World population data sheet 2011. Retrieved from http://www.prb.org/Publications/Datasheets/2011/worldpopulation-data-sheet/data-sheet

Samiee, S. (2011). Resolving the impasse regarding research on the origins of products and brands. International Marketing Review, 28 (5), 473-485.

Samiee, S., Shimp, T.A. \& Sharma, S. (2005). Brand origin recognition accuracy: Its antecedents and consumers' cognitive limitation. Journal of International Business Studies, 36, 379-397.

Schooler, R. (1971). Bias phenomena attendant to the marketing of foreign goods in the U.S. Journal of International Business Studies, 2, 71-80.

Schuiling, I. \& Kapferer, J.N. (2004). Real differences between local and international brands. Journal of International Marketing, 12 (4), 97-112.

Steenkamp, J-B.E.M., Batra, R. \& Alden, D.L. (2002). How perceived brand globalness creates brand value. Journal of International Business Studies, 34 (1), 1-13.

Thakor, M.V. \& Kohli, C.S. (1996). Brand origin: Conceptualization and review. Journal of Consumer Marketing, 13 (3), 27-42. 
Thakor, M.V. \& Lavack, A.N. (2003). Effect of perceived brand origin associations on consumer perception of quality. Journal of Product and Brand Management, 12 (6), 394-407.

The Jakarta Post (2013), S. Korea inks deals worth \$10b. Retrieved from http://www.thejakartapost.com/news/2013/10/12/s-korea-inks-deals-worth-10b.html

Tjiptono, F. (2010). Ketika sakit tak mengenal waktu. In Hartono, G. (ed.), Sukses Bisnis 24 Jam. (pp. 1-12). Yogyakarta: Penerbit Kanisius.

Usunier, J.C. (2011). The shift from manufacturing to brand origin. International Marketing Review, 28 (5), 486-496.

Venkatesh, A. \& Swamy, S. (1994). India as an emerging consumer society. In C.J. Schultz, II, Belk, R.W. \& Ger, G. (eds.), Research in consumer behavior. (Vol. 7, pp. 193-223). Greenwich, CT: JAI.

Wardi, R. \& Sihite, E. (2013). Indonesia, China set \$33b business pact. Retrieved from http://www.thejakartaglobe.com/news/indonesia-china-set-33b-business-pact/

Yasin, N. M., Noor, M.N. \& Mohamad, O. (2007). Does image of country-of-origin matter to brand equity. Journal of Product and Brand Management, 16 (1), 38-48.

Zhou, L., Yang, Z., \& Hui, M.K. (2010). Non-local or local brands? A multi-level investigation into confidence in brand origin identification and its strategic implications. Journal of the Academy of Marketing Science, 38, 202-218.

Zhou, N. \& Belk, R.W. (2004). Chinese consumer readings of global and local advertising appeals. Journal of Advertising, 33 (3), 63-76.

Zhuang, G., et al. (2008). Asymmetric effects of brand origin confusion. International Marketing Review, 25 (4), 441-457. 


\section{Appendices}

Table 1. Brands Used in the Present Study

\section{Local Brands}

Alfamart, Apotek K-24, Aqua, Bango, Buccheri, Cardinal, Dji Sam Soe, Eagle, Edward Forrer, Elizabeth, Excelso, Exsport, Filma, Gerry, Hemaviton, Indocafe, Inza, J.Co Donuts, Johnny Andrean, Kasogi, Lea, Lion Air, Lion Star, Maspion, Miyako, Mundo, New Era, Nexian, Nissin, Olympic, Paparonz, Polygon, Polytron, Roma, Sanken, SGM, Shinzui, Sosro, Supermi, Tango, Texas Chicken, Tje Fuk, Tong Tji, Zyrex.

\section{Foreign Brands}

Acer, Adidas, Agfa, Air Asia, Bata, Bayer, Bic, Blackberry, Canon, Carrefour, Chanel, Circle K, Citizen, Epson, Fuji, GAP, Goldstar, Hyundai, Jialing, Kodak, LG, Minolta, Motorola, NEC, Nestle, Nikon, Nissan, Nokia, Opel, Pampers, Pantene, Peugeot, Philips, Pocari Sweat, Puma, Reebok, Rolex, Rotiboy, Samsung, Swatch, TCL, TVS, Vespa, Zwitsal. 
Table 2. BORA for Foreign and Local Brands

\begin{tabular}{|c|c|c|c|c|c|c|}
\hline \multirow[b]{2}{*}{ Types of Brand } & \multicolumn{4}{|c|}{ BORA } & \multicolumn{2}{|c|}{ Paired Sample t-test } \\
\hline & $\%$ Correct & $\%$ Incorrect & \% Don't Know & Total & $\begin{array}{c}\text { Means of } \\
\text { BORA }\end{array}$ & $t$ (Sig.) \\
\hline \multicolumn{7}{|c|}{ Online Sample ( $n=163)$} \\
\hline Foreign Brands & 33.48 & 42.51 & 24.01 & 100 & 33.48 & \multirow{2}{*}{$\begin{array}{r}-16.381 \\
(0.000)\end{array}$} \\
\hline Local Brands & 56.65 & 27.69 & 15.66 & 100 & 56.65 & \\
\hline \multicolumn{7}{|c|}{ Offline Sample $(n=138)$} \\
\hline Foreign Brands & 23.25 & 43.07 & 33.68 & 100 & 23.25 & \multirow{2}{*}{$\begin{array}{r}-16.859 \\
(0.000) \\
\end{array}$} \\
\hline Local Brands & 50.56 & 28.03 & 21.41 & 100 & 50.56 & \\
\hline \multirow{2}{*}{\multicolumn{2}{|c|}{ Types of Brand }} & \multicolumn{4}{|c|}{ BORA Scores } & \multirow{2}{*}{ t-test (Sig.) } \\
\hline & & \multicolumn{2}{|c|}{ Online Sample } & \multicolumn{2}{|c|}{ Offline Sample } & \\
\hline \multicolumn{2}{|c|}{ Foreign Brands } & \multicolumn{2}{|c|}{33.48} & \multicolumn{2}{|c|}{23.25} & $4.996(0.000)$ \\
\hline \multicolumn{2}{|c|}{ Local Brands } & \multicolumn{2}{|c|}{56.65} & \multicolumn{2}{|c|}{50.56} & $2.629(0.009)$ \\
\hline
\end{tabular}


Table 3a. BORA for Each Country [Online Sample]

\begin{tabular}{|c|c|c|c|c|c|c|c|c|c|c|c|}
\hline \multirow{2}{*}{$\begin{array}{l}\text { Actual } \\
\text { Brand } \\
\text { Origin }\end{array}$} & \multicolumn{11}{|c|}{ Associated Brand Origin (\%) } \\
\hline & France & China & Indonesia & USA & Italy & Germany & UK & Switzerland & Japan & $\begin{array}{c}\text { Not } \\
\text { Listed }\end{array}$ & $\begin{array}{l}\text { Don't } \\
\text { Know }\end{array}$ \\
\hline France & $35.28^{a}$ & $1.38^{b}$ & 5.98 & 6.44 & 6.44 & 6.90 & 5.21 & 1.53 & 1.84 & 3.07 & 25.92 \\
\hline China & 0.00 & 65.34 & 6.44 & 0.92 & 0.61 & 0.31 & 0.31 & 0.00 & 2.76 & 4.91 & 18.40 \\
\hline Indonesia & 1.00 & 5.30 & 56.65 & 7.14 & 2.30 & 0.68 & 1.49 & 0.56 & 5.12 & 4.10 & 15.66 \\
\hline USA & 3.68 & 1.05 & 11.22 & 29.54 & 1.14 & 3.59 & 6.31 & 1.31 & 10.87 & 5.17 & 26.12 \\
\hline Italy & 1.23 & 2.45 & 4.29 & 1.23 & 40.49 & 15.95 & 0.61 & 0.61 & 4.91 & 4.29 & 23.93 \\
\hline Germany & 1.60 & 1.47 & 6.01 & 22.58 & 3.44 & 26.50 & 4.05 & 0.61 & 1.23 & 2.94 & 29.57 \\
\hline Switzerland & 2.45 & 0.20 & 8.18 & 12.07 & 2.04 & 4.70 & 6.75 & 34.56 & 3.07 & 4.70 & 21.27 \\
\hline Japan & 0.55 & 3.75 & 5.45 & 7.36 & 0.82 & 4.50 & 3.07 & 4.64 & 41.45 & 4.29 & 24.13 \\
\hline Means & 5.72 & 10.12 & 13.03 & 10.91 & 7.16 & 7.89 & 3.48 & 5.48 & 8.90 & 4.19 & 23.12 \\
\hline
\end{tabular}

Notes: a Indicates that $35.28 \%$ of respondents correctly associated French brands with France.

${ }^{b}$ Indicates that $1.38 \%$ of respondents incorrectly associated French brands with China.

Table 3b. BORA for Each Country [Offline Sample]

\begin{tabular}{|c|c|c|c|c|c|c|c|c|c|c|c|}
\hline \multirow{2}{*}{$\begin{array}{l}\text { Actual } \\
\text { Brand } \\
\text { Origin }\end{array}$} & \multicolumn{11}{|c|}{ Associated Brand Origin (\%) } \\
\hline & France & China & Indonesia & USA & Italy & Germany & UK & Switzerland & Japan & $\begin{array}{c}\text { Not } \\
\text { Listed } \\
\end{array}$ & $\begin{array}{l}\text { Don't } \\
\text { Know }\end{array}$ \\
\hline France & 24.46 & 2.36 & 7.79 & 8.88 & 4.17 & 6.88 & 2.36 & 1.45 & 0.91 & 2.72 & 38.04 \\
\hline China & 0.00 & 57.97 & 7.25 & 2.90 & 0.00 & 0.00 & 0.72 & 0.00 & 6.16 & 1.81 & 23.19 \\
\hline Indonesia & 1.20 & 6.49 & 50.56 & 7.33 & 2.72 & 0.81 & 1.56 & 0.51 & 4.81 & 2.60 & 21.41 \\
\hline USA & 3.11 & 2.90 & 18.01 & 19.57 & 2.80 & 4.04 & 2.38 & 0.93 & 8.49 & 3.73 & 34.06 \\
\hline Italy & 0.72 & 5.07 & 11.59 & 1.45 & 33.33 & 6.52 & 1.45 & 0.00 & 7.97 & 2.17 & 29.71 \\
\hline Germany & 2.90 & 2.32 & 7.54 & 17.97 & 5.07 & 15.36 & 2.46 & 1.45 & 1.88 & 1.30 & 41.74 \\
\hline Switzerland & 3.38 & 1.21 & 14.01 & 8.94 & 5.80 & 2.42 & 3.38 & 25.12 & 1.69 & 3.14 & 30.92 \\
\hline Japan & 1.29 & 5.15 & 7.65 & 6.12 & 1.21 & 4.11 & 1.53 & 2.90 & 31.56 & 2.42 & 36.07 \\
\hline Means & 4.63 & 10.43 & 15.55 & 9.14 & 6.89 & 5.02 & 1.98 & 4.05 & 7.93 & 2.49 & 31.89 \\
\hline
\end{tabular}


Table 4. Factors Associated with BORA

\begin{tabular}{|c|c|c|c|c|c|c|c|c|c|c|}
\hline \multirow{3}{*}{ Variable } & \multicolumn{5}{|c|}{ Online Sample } & \multicolumn{5}{|c|}{ Offline Sample } \\
\hline & \multirow[b]{2}{*}{ Number } & \multicolumn{2}{|c|}{ BORA (foreign) } & \multicolumn{2}{|c|}{ BORA (local) } & \multirow[b]{2}{*}{ Number } & \multicolumn{2}{|c|}{ BORA (foreign) } & \multicolumn{2}{|c|}{ BORA (local) } \\
\hline & & $\begin{array}{c}\text { Means } \\
(\%)\end{array}$ & F (Sig.) & $\begin{array}{c}\text { Means } \\
(\%)\end{array}$ & F (Sig.) & & $\begin{array}{c}\text { Means } \\
(\%)\end{array}$ & F (Sig.) & $\begin{array}{c}\text { Means } \\
(\%)\end{array}$ & F (Sig.) \\
\hline \multicolumn{11}{|l|}{ 1. Socio-economic characteristics } \\
\hline \multicolumn{11}{|l|}{ (a) Education levels } \\
\hline High school or less & 15 & 19.55 & \multirow{3}{*}{$\begin{array}{c}8.861 \\
\left(0.000^{\star \star \star}\right)\end{array}$} & 40.30 & \multirow{3}{*}{$\begin{array}{c}10.084 \\
\left(0.000^{\star \star \star}\right)\end{array}$} & 65 & 17.13 & \multirow{3}{*}{$\begin{array}{c}8.836 \\
\left(0.000^{\star \star \star}\right)\end{array}$} & 46.85 & \multirow{3}{*}{$\begin{array}{l}2.063 \\
(0.131)\end{array}$} \\
\hline Academy and undergraduate & 134 & 33.74 & & 56.46 & & 67 & 28.09 & & 53.32 & \\
\hline Postgraduates & 14 & 45.94 & & 75.97 & & 6 & 35.61 & & 53.41 & \\
\hline \multicolumn{11}{|l|}{ (b) Income levels per month } \\
\hline$<$ Rp 1 million - Rp 1,999,999 & 70 & 28.25 & \multirow{3}{*}{$\begin{array}{c}6.125 \\
\left(0.003^{\star \star \star}\right)\end{array}$} & 49.42 & \multirow{3}{*}{$\begin{array}{c}6.835 \\
\left(0.001^{\star \star \star}\right)\end{array}$} & 84 & 20.02 & \multirow{3}{*}{$\begin{array}{c}3.781 \\
\left(0.025^{\star \star}\right)\end{array}$} & 48.35 & \multirow{3}{*}{$\begin{array}{c}1.169 \\
(0.314)\end{array}$} \\
\hline Rp 2 million - Rp 3,999,999 & 52 & 35.88 & & 62.89 & & 39 & 28.03 & & 53.73 & \\
\hline$>$ Rp 4 million & 41 & 39.36 & & 61.09 & & 15 & 28.94 & & 52.12 & \\
\hline \multicolumn{11}{|l|}{ 2. International experience } \\
\hline \multicolumn{11}{|l|}{ (a) Foreign countries visited } \\
\hline Never & 58 & 30.76 & \multirow{4}{*}{$\begin{array}{c}0.731 \\
(0.535)\end{array}$} & 52.00 & \multirow{4}{*}{$\begin{array}{c}2.153 \\
\left(0.096^{\star}\right)\end{array}$} & 103 & 21.51 & \multirow{4}{*}{$\begin{array}{c}1.599 \\
(0.193)\end{array}$} & 49.89 & \multirow{4}{*}{$\begin{array}{c}1.447 \\
(0.232)\end{array}$} \\
\hline 1 & 52 & 35.23 & & 57.21 & & 21 & 26.41 & & 50.87 & \\
\hline $2-3$ & 33 & 35.26 & & 64.33 & & 6 & 29.55 & & 64.02 & \\
\hline More than 3 & 20 & 33.86 & & 56.02 & & 8 & 32.67 & & 43.47 & \\
\hline (b) Foreign language spoken & & & & & & & & & & \\
\hline 0 & 14 & 26.95 & & 48.70 & & 38 & 14.89 & & 41.51 & \\
\hline 1 & 108 & 33.97 & & 57.72 & & 79 & 27.16 & & 55.15 & \\
\hline 2 & 33 & 33.33 & $\begin{array}{c}0.901 \\
(0.465)\end{array}$ & 53.72 & $\begin{array}{c}1.673 \\
(0.159)\end{array}$ & 17 & 19.79 & $\begin{array}{c}4.949 \\
(0.001 * * *)\end{array}$ & 44.65 & 4.746 \\
\hline 3 & 7 & 36.69 & & 63.96 & & 3 & 35.60 & & 56.82 & \\
\hline 4 & 1 & 54.55 & & 97.73 & & 1 & 54.55 & & 75.00 & \\
\hline 3. Demographic factors & & & & & & & & & & \\
\hline (a) Gender & & & & & & & & & & \\
\hline Male & 86 & 33.11 & 0.076 & 55.68 & 0.334 & 35 & 27.73 & 3.073 & 51.04 & 0.076 \\
\hline Female & 77 & 33.88 & $0.783)$ & 57.73 & $(0.564)$ & 103 & 21.73 & $\left(0.082^{*}\right)$ & 50.02 & $(0.784)$ \\
\hline (b) Age & & & & & & & & & & \\
\hline$<18$ & 1 & 4.55 & & 34.09 & & 4 & 10.80 & & 46.03 & \\
\hline $18-24$ & 43 & 30.13 & & 52.48 & & 64 & 18.93 & & 49.93 & \\
\hline $25-34$ & 103 & 34.55 & 1.575 & 57.88 & 0.778 & 43 & 28.75 & 3.704 & 53.49 & 3.357 \\
\hline $35-44$ & 10 & 40.23 & $(0.170)$ & 63.86 & $(0.567)$ & 13 & 20.28 & $\left(0.004^{\star \star \star}\right)$ & 33.92 & $\left(0.007^{\star \star \star}\right)$ \\
\hline $45-54$ & 5 & 36.82 & & 58.64 & & 3 & 46.97 & & 70.45 & \\
\hline $55-64$ & 1 & 11.36 & & 50.00 & & 11 & 28.51 & & 55.16 & \\
\hline
\end{tabular}

Notes: ${ }^{\star \star \star}=$ significant at $\rho=1 \% ;{ }^{* \star}=$ significant at $\rho=5 \% ;{ }^{*}=$ significant at $\rho=10 \%$. 